\title{
Childhood Adrenal Gland Pheochromocytoma
}

National Cancer Institute

\section{Source}

National Cancer Institute. Childhood Adrenal Gland Pheochromocytoma. NCI Thesaurus.

Code C118822.

A rare pheochromocytoma of the adrenal gland that occurs during childhood. 